\title{
Catch crop strategy and nitrate leaching following grazed grass-clover
}

\author{
E. M. Hansen, J. Eriksen \& F. P. Vinther \\ Department of Agroecology and Environment, Faculty of Agricultural Sciences, University of Aarhus, PO Box 50, DK-8830 Tjele, \\ Denmark
}

\begin{abstract}
Cultivation of grassland presents a high risk of nitrate leaching. This study aimed to determine if leaching could be reduced by growing spring barley (Hordeum vulgare L.) as a green crop for silage with undersown Italian ryegrass (Lolium multiflorum Lam.) compared with barley grown to maturity with or without an undersown conventional catch crop of perennial ryegrass (Lolium perenne L.). All treatments received 0,60 or $120 \mathrm{~kg}$ of ammonium- $\mathrm{N}$ ha ${ }^{-1}$ in cattle slurry. In spring 2003, two grassclover fields ( 3 and 5 years old, respectively, with different management histories) were ploughed. The effects of the treatments on yield and nitrate leaching were determined in the first year, while the residual effects of the treatments were determined in the second year in a crop of spring barley/perennial ryegrass. Nitrate leaching was estimated in selected treatments using soil water samples from ceramic cups. The experiment showed that compared with treatments without catch crop, green barley/Italian ryegrass reduced leaching by $163-320 \mathrm{~kg} \mathrm{~N} \mathrm{ha}^{-1}$, corresponding to $95-99 \%$, and the perennial ryegrass reduced leaching to between 34 and $86 \mathrm{~kg} \mathrm{~N} \mathrm{ha}^{-1}$, corresponding to a reduction of 80 and $66 \%$. Also, in the second growing season, leaching following catch crops was reduced compared with the bare soil treatment. It was concluded that the green barley/Italian ryegrass offers advantages not only for the environment but also for farmers, for whom it provides a fodder high in roughage and avoids the difficulties with clover fatigue increasingly experienced by Danish farmers.
\end{abstract}

Keywords: Nitrate leaching, grass-clover, cultivation, Italian ryegrass, perennial ryegrass, catch crop

\section{Introduction}

When a grass-clover ley is ploughed, there is a high risk of nitrate leaching (e.g. Djurhuus \& Olsen, 1997; Eriksen et al., 1999), especially on sandy soils under relatively humid climatic conditions. The risk is dependent on the preceding management of the grass-clover, as the amount of $\mathrm{N}$ accumulated in the soil increases with length of time under grass, and more so with a grazing rather than a cutting regime, as summarized by Eriksen (2001).

On loamy soils Shepherd et al. (2001) showed that the risk of nitrate leaching is negligible if grass is resown in spring shortly after ploughing. But they emphasized that the method has a practical disadvantage for the farmer because of reduced grass production in the first year of the new sward.

Undersowing a catch crop in a spring cereal following spring ploughing of grass-clover (Djurhuus \& Olsen, 1997)

Correspondence: E. M. Hansen. E-mail: elly.m.hansen@agrsci.dk Received May 2007; accepted after revision June 2007 has been shown to successfully reduce nitrate leaching the following autumn and winter (Djurhuus, 1992; Thomsen \& Christensen, 1999). However, sometimes this beneficial effect of the catch crop is less than expected. Reasons for this could be delayed harvest of the main crop and heavy rain after harvest, which may leach nitrate below the root zone of the catch crop (Davies et al., 1996; Hansen \& Djurhuus, 1997), or the $\mathrm{N}$ uptake capacity of the undersown catch crop has been exceeded (Torstensson \& Aronsson, 2000). Knowledge about best practice concerning management of previous grass-clover leys on sandy soils is therefore still lacking.

A catch crop should be established early enough to enable significant amounts of $\mathrm{N}$ to be taken up before leaching starts in the autumn. Vigorous undersown grasses have the ability to take up large amounts of N (Simmelsgaard, 1991), but they may also result in competition between the catch crop and the main crop. This can result in reduced main crop yields (Andersen \& Olsen, 1993; Karlsson-Strese et al., 1998) and loss of income for the farmer. But if the farmer is able to utilize the catch crop, the main crop yield reduction may be compensated by additional roughage. 
Italian ryegrass is known as a vigorously growing grass (Andersen \& Olsen, 1993), and in the early 1980s Italian ryegrass was recommended to Danish dairy farmers as the most suitable catch crop in spring barley production (Jacobsen \& Bentholm, 1981). However, many dairy farmers used spring barley crops to establish grass-clover leys, and the growing of spring barley/Italian ryegrass did not become widespread. However, in the early 2000s, organic dairy farmers experienced increasing difficulties with 'clover soil fatigue' due to continuous cultivation of grass-clover. The effects of this condition are that clover plants emerge, become stunted and eventually disappear during the same year (Søegaard \& Møller, 2006).

A new interest in growing spring barley/Italian ryegrass as a green crop for silage has been enhanced by the marketing of tetraploid varieties of Italian ryegrass with a higher sugar content than diploid varieties (Nielsen et al., 2005).

The objective of the study was to test the efficiency of Italian ryegrass as a catch crop on sandy soil undersown in barley and used as a green crop for silage after ploughing of differently managed grass-clover leys. The green barley/Italian ryegrass treatment was compared with barley grown to maturity with and without an undersown conventional catch crop of perennial ryegrass. This paper focuses on the leaching of inorganic $\mathrm{N}$ during a period of 2 years following the cultivation of grass-clover leys. Leaching of dissolved organic $\mathrm{N}$ (DON) and carbon (DOC) in selected treatments during the first year of the experiment have previously been reported (Vinther et al., 2006).

\section{Materials and methods}

Experiments were initiated in spring 2003 by ploughing two grass-clover fields on a commercial organic farm in the southern part of Denmark $\left(9^{\circ} 05^{\prime} \mathrm{E}, 54^{\circ} 53^{\prime} \mathrm{N}\right)$ : (1) a 3 -year-old grass-clover field, which had formed part of a crop rotation dominated by cereals; and (2) a 5-year-old grass-clover field, which was part of a intensive grass rotation grazed by dairy cows.

Table 1 Precipitation for 3-month periods and average temperature for DecemberFebruary at Jyndevad meteorological station
The 3-year-old grass-clover was established by undersowing in oats (Avena sativa L.) in 1999 and was mainly used for cutting. The 5-year-old grass-clover had been used as a large pen for grazing cows. It was established by undersowing in oats in 1997.

The soil was a coarse sandy soil with clay $(<2 \mu \mathrm{m})$, silt $(2-63 \mu \mathrm{m})$ and sand $(63-2000 \mu \mathrm{m})$ contents at $0-25 \mathrm{~cm}$ of 67, 127 and $708 \mathrm{~g} \mathrm{~kg}^{-1}$ and 46, 67 and $832 \mathrm{~g} \mathrm{~kg}^{-1}$ for the 3 and 5-year-old grass-clover fields, respectively. The organic matter contents were 98 and $55 \mathrm{~g} \mathrm{~kg}^{-1}$ and soil $\mathrm{pH}(0.01 \mathrm{M}$ $\mathrm{CaCl}_{2}$, soil/water proportion $\left.1: 2.5\right)$ was 6.3 and 6.5 , exchangeable $\mathrm{K}(0.5 \mathrm{~m}$ ammonium acetate $) 61$ and $17 \mathrm{mg}$ $\mathrm{kg}^{-1}$ dry soil and extractable $\mathrm{P}\left(0.5 \mathrm{~m} \mathrm{NaHCO}_{3}\right)$ was 96 and $14 \mathrm{mg} \mathrm{kg}^{-1}$ dry soil, respectively.

The farm was situated $4 \mathrm{~km}$ west of the Jyndevad meteorological station, which has a long-term mean precipitation of $858 \mathrm{~mm}$ year $^{-1}$ and an average mean temperature of $7.9{ }^{\circ} \mathrm{C}$ (Table 1). The winter before the grass-clover fields were ploughed (2002-2003) was cooler than the long-term mean (Table 1), while the winters 2003-2004 and 2004-2005 were warmer. Precipitation during June-August was higher than average in the first experimental year (2003) and close to the long-term mean in the second year (Table 1).

The fields were not irrigated due to sufficient precipitation during the two growing periods. In each field, the treatments were arranged in a randomized block design with four replicates. The gross/net area of each plot was $48 / 18 \mathrm{~m}^{2}$.

\section{Year 1}

Before ploughing on 25 March 2003, the grass-clover was rotovated on 3 March 2003 to increase synchrony between $\mathrm{N}$ mineralization and plant $\mathrm{N}$ uptake due to an earlier start of decomposition of the grass-clover (Eriksen \& Jensen, 2001). After ploughing, the following treatments were established in both fields (Table 2): (1) spring barley harvested early as a green crop for silage with an undersown catch crop of Italian ryegrass, which was mown twice in the autumn; (2) spring barley harvested at maturity with an undersown catch crop of perennial ryegrass; and (3) spring barley harvested at

\begin{tabular}{lcccc}
\hline \multicolumn{4}{c}{ Long-term mean } & \\
\cline { 2 - 5 } & $1961-1990$ & $2002-2003$ & $2003-2004$ & $2004-2005$ \\
\hline Precipitation (mm) & & & & \\
December-February & 188 & 120 & 271 & 209 \\
March-May & 160 & 157 & 113 & 187 \\
June-August & 227 & 174 & 313 & 234 \\
September-November & 283 & 184 & 277 & 192 \\
December-November & 858 & 635 & 974 & 822 \\
Temperature in & 0.6 & -0.1 & 2.0 & 2.7 \\
December-February $\left({ }^{\circ} \mathrm{C}\right)$ & & & & \\
\hline
\end{tabular}


Table 2 Treatments following ploughing of grass-clover swards in spring 2003

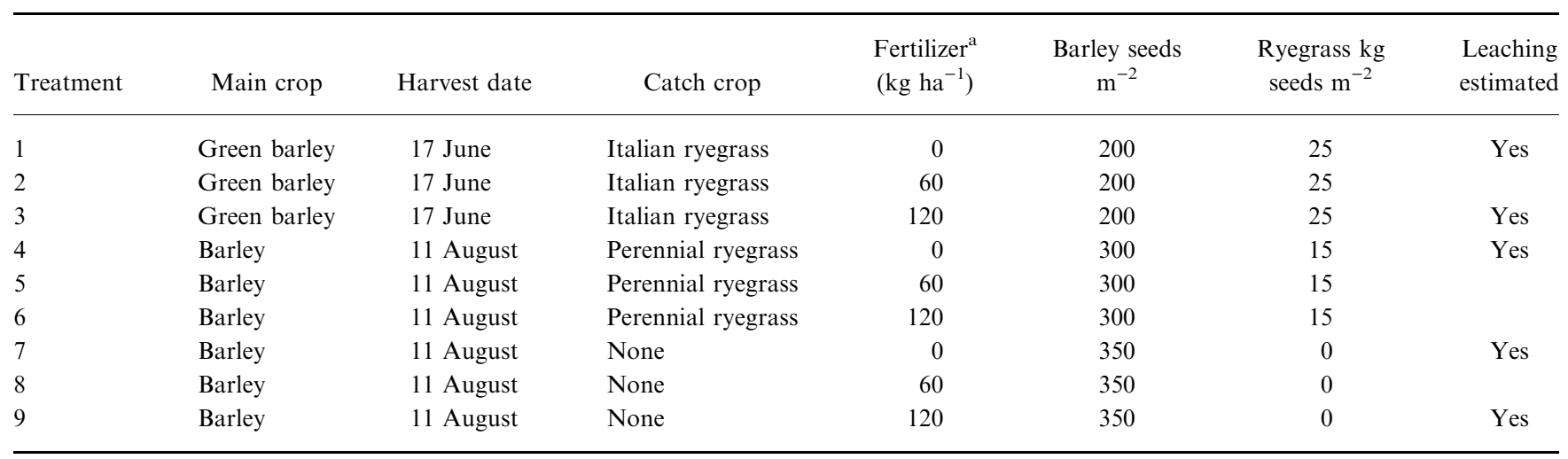

${ }^{a} \mathrm{~kg}$ ammonium- $\mathrm{N}$ in cattle slurry injected before sowing.

maturity and subjected to mechanical weed control in the autumn. The treatments were fertilized on 27 March 2003 with 0,60 or $120 \mathrm{~kg}$ of ammonium-N ha ${ }^{-1}(0,99$ or $198 \mathrm{~kg}$ total- $\left.\mathrm{N} \mathrm{ha}^{-1}\right)$ in cattle slurry $\left(72 \mathrm{~g} \mathrm{DM} \mathrm{kg}^{-1}\right.$ slurry, $56 \mathrm{~g}$ total- $\mathrm{N} \mathrm{kg}^{-1} \mathrm{DM}$ and $34 \mathrm{~g} \mathrm{NH}_{4}-\mathrm{N} \mathrm{kg}^{-1} \mathrm{DM}$ ) injected into the ploughed soil (Table 2). The spring barley was a variety mixture (Cisero, Punto and Otiro), the perennial ryegrass was 'Lasso' and the Italian ryegrass used was a tetraploid variety called 'Ajax'.

Spring barley (Hordeum vulgare L.) was sown on 1 April 2003. Perennial ryegrass was undersown in spring barley and Italian ryegrass was undersown in the green-harvested spring barley. Harvest of green barley for silage was carried out on 17 June 2003, allowing the undersown Italian ryegrass to develop. The Italian ryegrass was cut twice on 15 August and 20 October 2003, and the perennial ryegrass was cut once on 20 October 2003. In treatments without catch crops or perennial ryegrass, the spring barley was harvested at maturity on 11 August 2003, and in the former the soil was kept free of vegetation by rotary cultivation twice on 26 September and 21 October 2003. Weeds were controlled by two passes of a spring tine weeder on 23 April and 9 May 2003 after spring barley germination on 14 April 2003, but before undersowing of the two grasses on 9 May 2003.

\section{Year 2}

In the second year, all plots were treated identically. Plots were ploughed on 19 April 2004 and spring barley was sown on 30 April 2004 and perennial ryegrass on 24 May 2004 (same varieties and amounts as in 2003, Table 2). All plots were fertilized on 23 April 2004 with $60 \mathrm{~kg}$ of ammonium$\mathrm{N} \mathrm{ha}^{-1}$ in cattle slurry (42 $\mathrm{g} \mathrm{DM} \mathrm{kg}^{-1}$ slurry, $71 \mathrm{~g}$ total$\mathrm{N} \mathrm{kg}^{-1} \mathrm{DM}$ and $40 \mathrm{~g} \mathrm{NH}_{4}-\mathrm{N} \mathrm{kg}^{-1} \mathrm{DM}$ ) injected into the ploughed soil. To control weeds a spring tine weeder was used once on 13 May 2004 after spring barley germination on 9 May 2004. Spring barley was harvested at maturity on 26 August 2004 and the perennial ryegrass was left uncut.

\section{Nitrate in soil water}

For calculation of nitrate leaching, soil water was taken using porous ceramic cup samplers installed at 100-cm depth in spring 2003 from selected treatments (Table 2). Due to a rising groundwater level during autumn 2003, the suction cups were reinstalled at $70 \mathrm{~cm}$ depth on 12 December 2003. The equipment and installation were as described by Djurhuus \& Jacobsen (1995). Two samplers were installed per plot (i.e. eight per treatment). A suction of approximately 70-80 kPa was imposed 2-3 days before sampling. During this period, the suction decreased as a result of sampling water. The soil water samples from each replicate were bulked before analysis, frozen within a few hours and later analysed for nitrate N (Best, 1976) on a Technicon Auto Analyzer (Tarrytown, NY, USA) after the addition of tartrate. Generally, sampling was carried out once every 2 weeks, except in periods of drought or frost. Percolation was calculated using the model EVACROP 3.0, which is an updated version of EVACROP 1.5 (Olesen \& Heidmann, 1990). Nitrate leaching was estimated using the trapezoidal rule (Lord \& Shepherd, 1993), assuming that nitrate concentrations in the extracted soil water represented average flux concentrations. The accumulated leaching was calculated from the beginning of April to the end of March.

\section{Plant samples}

Roots of each sward type were sampled immediately before the start of tillage operations in 2003. In each sward 20 soil cores (46 mm diameter) were sampled to a depth of $20 \mathrm{~cm}$ for determination of root biomass (Eriksen \& Jensen, 2001). Determination of the corresponding above ground biomass was planned, but the sward height at that time was too low to obtain a sample. Dry matter, $\mathrm{C}$ and $\mathrm{N}$ contents were determined in all root samples.

Barley was harvested with a plot combine. In 2004, grain and straw samples were oven dried at $80^{\circ} \mathrm{C}$ and total $\mathrm{N}$ 
Table 3 DM yield and N uptake in above ground catch crop in spring $2004( \pm \mathrm{SE})$

\begin{tabular}{|c|c|c|c|c|c|}
\hline Main crop and fertilizer & Catch crop & $\begin{array}{l}\text { DM yield } \\
\left(\mathrm{kg} \mathrm{ha}^{-1}\right)\end{array}$ & $\begin{array}{c}\text { N uptake } \\
\left(\mathrm{kg} \mathrm{N} \mathrm{ha}^{-1}\right)\end{array}$ & $\begin{array}{l}\text { DM yield } \\
\left(\mathrm{kg} \mathrm{ha}^{-1}\right)\end{array}$ & $\begin{array}{c}\text { N uptake } \\
\left(\mathrm{kg} \mathrm{N} \mathrm{ha}^{-1}\right)\end{array}$ \\
\hline Barley, 0N & Perennial ryegrass & $732 \pm 72$ & $21 \pm 1.6$ & $707 \pm 127$ & $23 \pm 3.8$ \\
\hline Barley, $60 \mathrm{~N}$ & Perennial ryegrass & $673 \pm 71$ & $23 \pm 3.4$ & $564 \pm 51$ & $17 \pm 1.3$ \\
\hline Green barley, $60 \mathrm{~N}$ & Italian ryegrass & $1075 \pm 80$ & $29 \pm 3.8$ & $1091 \pm 119$ & $31 \pm 4.8$ \\
\hline Green barley, $120 \mathrm{~N}$ & Italian ryegrass & $1059 \pm 104$ & $29 \pm 3.8$ & $1226 \pm 212$ & $33 \pm 6.7$ \\
\hline
\end{tabular}

determined by the Dumas method (Hansen, 1989). Green barley was harvested as wholecrop and samples of the barley/Italian ryegrass mixture and cut grasses were analysed as described above. In 2005, the dry matter content of barley grain was determined by a near-infrared spectroscopy analyser (Infratec ${ }^{\mathrm{TM}} 1241$ Grain Analyzer, Foss A/S; Buchmann et al., 2001) in which protein content was also determined. The $\mathrm{N}$ content barley was calculated using a protein factor of 6.25 .

In spring and autumn 2004, shoot material from grasses were taken from a $2 \times 0.5 \mathrm{~m}$ area in each plot and total $\mathrm{N}$ determined (Table 3) by the Dumas method (Hansen, 1989).

\section{Results and discussion}

\section{Incorporated plant residues}

Sampling of roots in spring is difficult and subject to great uncertainty, but it gives an indication of the presence and differences in the content of plant material incorporated. In the 3-year-old pasture, $6.4 \mathrm{t} \mathrm{DM} \mathrm{ha}^{-1}(\mathrm{CV} \mathrm{62 \% )}$ was found in the top $20 \mathrm{~cm}$ of the soil compared with $11.8 \mathrm{t}$ (CV 57\%) in the 5-year-old pasture. The quantities of plant roots were greater than these found in other studies (e.g. Høgh-Jensen \& Schjoerring, 1997; Hauggaard-Nielsen et al., 1998), which may be due to the older age of the pastures. The results corresponded well with Eriksen et al. (2006) who found 6.6-10.3 $\mathrm{t} \mathrm{DM} \mathrm{ha}^{-1}$ in grazed pastures of different age with the largest value in an 8 -year-old pasture. The $\mathrm{C}$ to $\mathrm{N}$ ratio of the root material was $23(\mathrm{CV} \mathrm{13 \% )}$ in the 3-year-old pasture and $18(\mathrm{CV} 9 \%)$ in the 5-year-old pasture. This corresponded to an $\mathrm{N}$-content in root material of 116 and $230 \mathrm{~kg} \mathrm{ha}^{-1}$ in the 3- and 5-year-old pastures, respectively. The $\mathrm{C}$ to $\mathrm{N}$ ratios of $18-23$ are in accordance with a $\mathrm{C}$ to $\mathrm{N}$ ratio of 20 (corresponding to $194 \mathrm{~kg} \mathrm{~N} \mathrm{ha}^{-1}$ ) in grass-clover roots in a pasture grazed by cows with a high intake of $\mathrm{N}$ (Eriksen, 2001). The $\mathrm{C}$ to $\mathrm{N}$ ratio of less than 25 indicates that mineralization takes place shortly after incorporation (Kyllingsbæk, 1992; Trinsoutrot et al., 2000), which explains the large $\mathrm{N}$ availability for crop uptake and leaching.

\section{Nitrate concentrations}

Nitrate concentrations in suction cups under the treatment without catch crops after ploughing of the grass-clover leys were approximately $100 \mathrm{mg} \mathrm{L}^{-1} \mathrm{NO}_{3}-\mathrm{N}$ or above when concentrations were the highest during autumn/winter 2003/2004 (Figure 1). In an experiment by Djurhuus \& Olsen (1997) on a coarse sandy soil, nitrate concentrations after spring ploughing of cut grass-clover never exceeded $50 \mathrm{ppm} \mathrm{NO}_{3}-\mathrm{N}$. However, in their experiment of Djurhuus $\&$ Olsen (1997), the ploughed ley was only 1 year old. Nitrate concentrations are affected by the amount of precipitation.

The high nitrate concentrations after the 3- and 5-year old leys could be caused by several factors: (1) a high soil organic matter content of $98 \mathrm{~g} \mathrm{~kg}^{-1}$ in the 3 -year-old and $55 \mathrm{~g} \mathrm{~kg}^{-1}$ in the 5-year-old ley; (2) intensive grazing of the 5 -year-old ley; (3) clover populations that had been well maintained and evenly distributed in both fields until ploughing; (4) rotovation of the treatment without catch crops twice in autumn, which may have increased mineralization and prevented weeds from taking up $\mathrm{N}$, as discussed later; and (5) application of a considerable $\mathrm{N}$ load of $120 \mathrm{~kg} \mathrm{ha}^{-1}$ of ammonium-N and $78 \mathrm{~kg} \mathrm{ha}^{-1}$ of organic-N to treatments fertilized with the largest slurry treatment.

In spring 2004 (1 year after ploughing of the grass-clover), nitrate concentrations were relatively high in treatments without catch crops and remained high during the summer, indicating that the barley was unable to take up the nitrate situated at the base of the root zone.

In contrast to the high nitrate concentrations in treatments without a catch crop, concentrations under Italian ryegrass were extremely low until autumn 2004, indicating very efficient $\mathrm{N}$ uptake. The increase in nitrate concentrations under perennial ryegrass in autumn 2004 following the Italian ryegrass treatment with 0 and $120 \mathrm{~kg} \mathrm{~N} \mathrm{ha}^{-1}$ indicates that the perennial ryegrass grown in 2004 was not as efficient in taking up $\mathrm{N}$ as the Italian ryegrass grown previously. This agrees with the results from the first year where the nitrate concentrations in the perennial 


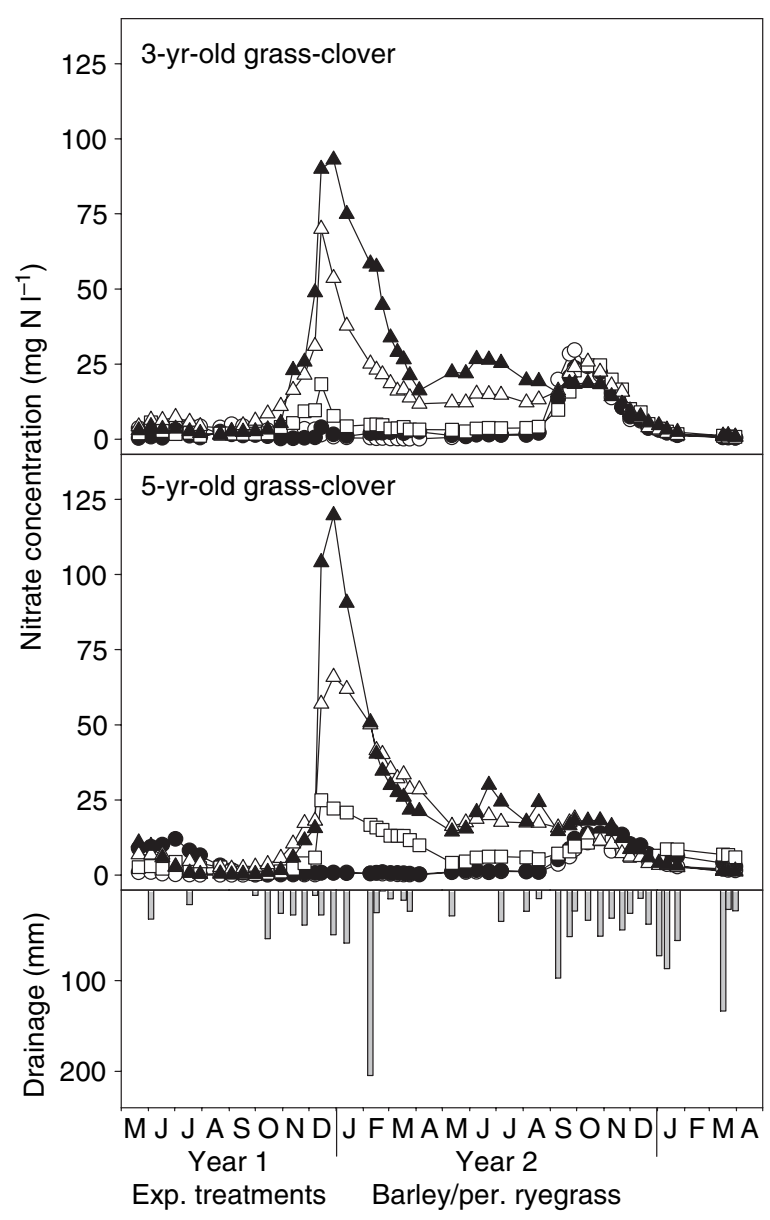

$$
\begin{aligned}
& \text { Experimental treatments year } 1 \\
& \text { - - Green barley - Ital. ryegr. ON } \\
& \text { - Green barley - Ital. ryegr. } 120 \mathrm{~N} \\
& \square-\text { Barley - per. ryegr. ON } \\
& \triangle-\text { Barley - no catch crop ON } \\
& \simeq \text { Barley - per. ryegr. } 120 \mathrm{~N}
\end{aligned}
$$

Figure 1 Nitrate concentrations in soil water $(100 \mathrm{~cm})$ for 2 years following ploughing of 3- and 5-year-old grass-clover swards. The treatments refer to year 1 ; in year 2 , all plots were treated identically (Barley/perennial ryegrass, $60 \mathrm{~N}$ ). Estimated drainage (accumulated since the last nitrate sampling date) is shown for treatments without catch crops.

ryegrass treatment were higher than in the Italian ryegrass treatment.

The nitrate concentrations at the beginning of the experiment were generally below $10 \mathrm{mg} \mathrm{L}^{-1}$ (Figure 1) suggesting that the nitrate content under the grass-clover fields was small. This is probably due to efficient $\mathrm{N}$ uptake by the grass-clover, even though nitrate concentrations on these soils usually decrease to a low level during winter (Hansen \& Djurhuus, 1997). The low nitrate concentrations in soil water at the beginning of the experiment are in agreement with small nitrate contents in soil samples from 50 to $100 \mathrm{~cm}$ of only 6-9 $\mathrm{kg} \mathrm{ha}^{-1}$ nitrate-N (data not shown). The whole soil profile contained $18-23 \mathrm{~kg} \mathrm{ha}^{-1}$ nitrate- $\mathrm{N}$ and $40-44 \mathrm{~kg} \mathrm{ha}^{-1}$ ammonium N. Most of the mineral $\mathrm{N}$ (nitrate $\mathrm{N}$ and ammonium $\mathrm{N}$ ) was found at $0-20 \mathrm{~cm}$, which on average contained $36 \mathrm{~kg} \mathrm{ha}^{-1} \mathrm{~N}$, while the content at $20-50$ and $50-100 \mathrm{~cm}$ was $13 \mathrm{~kg} \mathrm{ha}^{-1} \mathrm{~N}$ in both. Thus, leaching during the following autumn and winter mainly originated from mineralization of organic matter or from excess fertilizer and not directly from previous management of the grass-clover leys.

\section{Nitrate leaching}

In the first year, nitrate leaching after barley without catch crop was 171 and $256 \mathrm{~kg} \mathrm{~N}^{-1}$ following the 3- and the 5-year-old grass-clover, respectively (Figure 2). When applying $120 \mathrm{~kg} \mathrm{~N}^{-1}$ without catch crops, leaching was 297 and $327 \mathrm{~kg} \mathrm{~N} \mathrm{ha}^{-1}$. Because of the high nitrate concentrations, nitrate leaching without catch crops was large in comparison to previous Danish field experiments. In the above-mentioned experiment on coarse sandy soil (Djurhuus \& Olsen, 1997), nitrate leaching after a 1-year-old cut grass-clover was only approximately $100 \mathrm{~kg} \mathrm{~N} \mathrm{ha}^{-1}$ in the first year after ploughing of the grass-clover.

After barley with Italian ryegrass leaching was only 3-9 $\mathrm{kg} \mathrm{N} \mathrm{ha}^{-1}$. This is less than the $17 \mathrm{~kg} \mathrm{~N} \mathrm{ha}^{-1}$ estimated by Simmelsgaard (1998) for grass, but similar to leaching from grazed grass-clover swards receiving no fertilizer $\mathrm{N}$ input (Macduff et al., 1990). Compared with treatments without a catch crop, the Italian ryegrass reduced leaching by $163-320 \mathrm{~kg} \mathrm{~N}^{-1}$, corresponding to $95-99 \%$.

The perennial ryegrass reduced leaching to between 34 and $86 \mathrm{~kg} \mathrm{~N} \mathrm{ha}^{-1}$ corresponding to a reduction of between 66 and $80 \%$ (Figure 2) compared with treatments without a catch crop. The larger value is greater than those of Eriksen (2001), who reported leaching of approximately $50 \mathrm{~kg} \mathrm{~N} \mathrm{ha}^{-1}$ or less in spring cereals with undersown perennial ryegrass in the first year after ploughing of 3-year-old grass-clover leys. In both fields, leaching was significantly greater under perennial ryegrass than under Italian ryegrass treatments without fertilizer application. Thus, the vigorous undersown Italian ryegrass showed its ability to take up large amounts of $\mathrm{N}$ after early harvest of barley as a green crop. Early harvest as wholecrop allows more time for the development of the catch crop than harvest of the barley at maturity as in the perennial ryegrass treatment.

The second summer (2004) was wet and almost $100 \mathrm{~mm}$ of drainage caused significantly more leaching after treatments without catch crops ( 0 and $\left.120 \mathrm{~kg} \mathrm{~N} \mathrm{ha}^{-1}\right)$ than after perennial and Italian ryegrass treatments (Figure 2). Because all plots were growing spring barley with perennial ryegrass at that time, the differences in leaching were a carry-over effect from the previous treatments. As seen in Figure 1, the nitrate concentrations at the bottom of the root zone were lower 
Figure 2 Nitrate leaching for 2 years following ploughing of 3- and 5-year-old grassclover swards. The treatments refer to year 1 ; in year 2 , all plots were treated identically. Significant differences were identified after log-transformation. Bars with the same letter are not significantly different $(P<0.05)$. Annual leaching in year 2 was divided into summer (April to harvest) and autumn/winter (harvest to March). No significant differences were found between treatments for autumn/winter leaching.
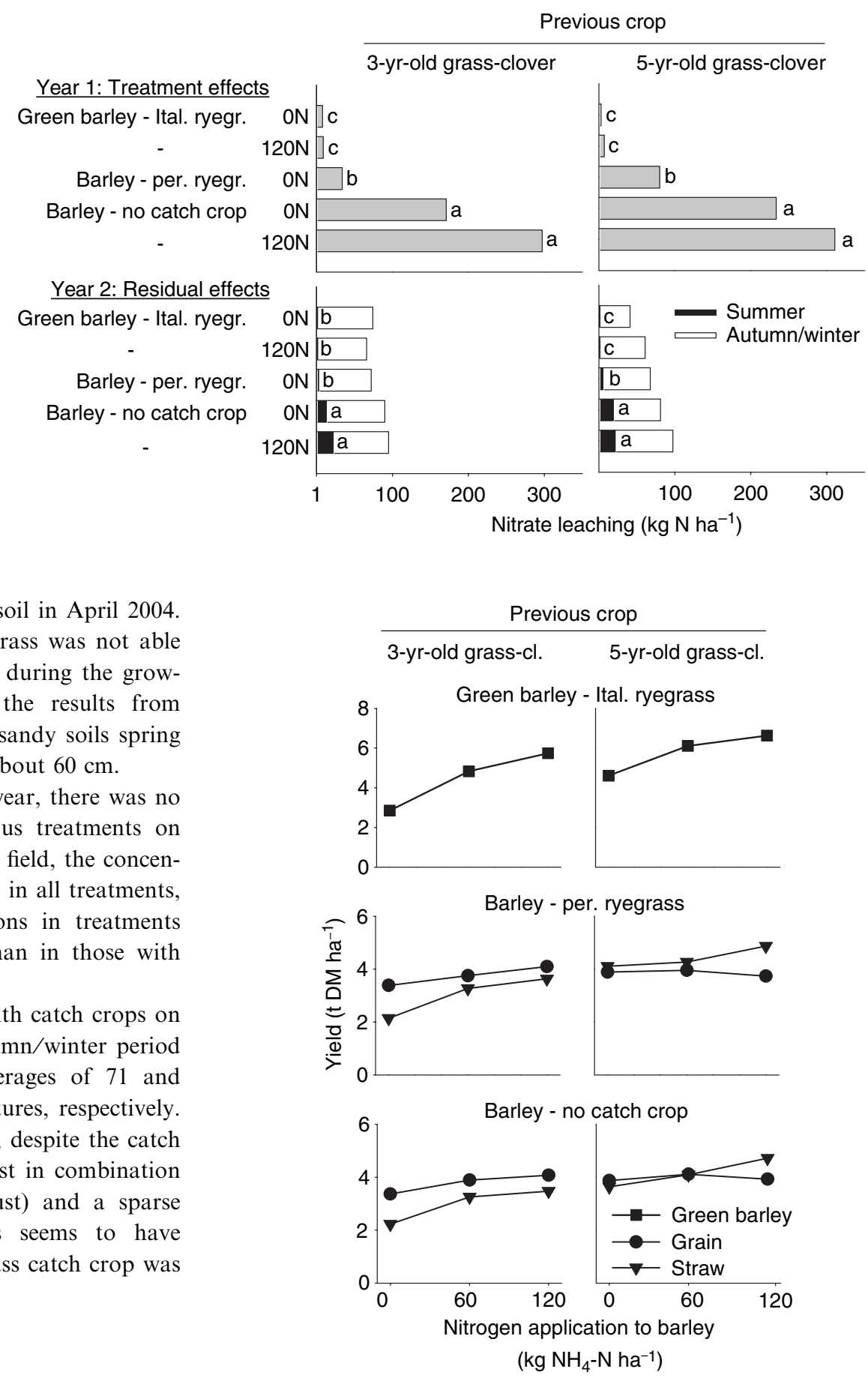

following catch crops than following bare soil in April 2004. Apparently, the barley with perennial ryegrass was not able to reduce the concentrations at that depth during the growing season. This is in agreement with the results from Madsen (1978) who found that on coarse sandy soils spring barley developed roots only to a depth of about $60 \mathrm{~cm}$.

During the winter period of the second year, there was no difference in the residual effect of previous treatments on leaching levels (Figure 2). In the 3-year-old field, the concentrations just after harvest 2004 were similar in all treatments, while in the 5-year-old field, concentrations in treatments without a catch crop were still greater than in those with catch crops (Figure 1).

In comparison with other experiments with catch crops on coarse sandy soil, leaching during the autumn/winter period of the second year was greater with averages of 71 and $56 \mathrm{~kg} \mathrm{~N} \mathrm{ha}^{-1}$ in the 3- and 5-year-old pastures, respectively. The relatively large quantity of nitrate loss, despite the catch crop, may be due to wet weather in August in combination with the late harvest of barley (26 August) and a sparse development of perennial ryegrass. This seems to have caused leaching of nitrate before the ryegrass catch crop was fully developed.

\section{Main crop year 1}

Grain yields of unfertilized barley without a catch crop were 3.4 and $3.9 \mathrm{t} \mathrm{DM} \mathrm{ha}^{-1}$, and total yield of unfertilized green barley for silage was 6.5 and $9.7 \mathrm{t} \mathrm{DM} \mathrm{ha}^{-1}$ in green crop and grass in the 3- and 5-year-old pastures, respectively (Figures 3 and 4). As described above, in the treatments without a catch crop an additional approximately $100 \mathrm{~kg} \mathrm{~N}^{-1}$ was leached when $120 \mathrm{~kg}$ of ammonium-N ha ${ }^{-1}$ was applied (Figure 2). This was matched by a relatively small yield response to the $\mathrm{N}$ applications (Figure 3). By contrast, leaching from
Figure 3 Yield of green barley, and grain and straw from barley harvested at maturity following ploughing of 3- and 5-year-old grass-clover swards.

treatments with Italian ryegrass remained small and were not affected by slurry $\mathrm{N}$ application (Figure 2). This is explained by the additional $\mathrm{N}$ uptake of on average $127 \mathrm{~kg} \mathrm{~N}$ ha $^{-1}$ in green barley from applying $120 \mathrm{~kg} \mathrm{~N} \mathrm{ha}^{-1}$ (Figure 5), showing 


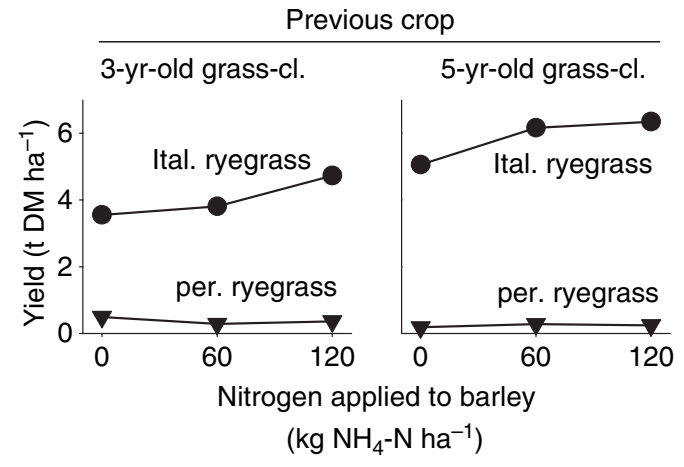

Figure 4 Yields of Italian ryegrass following green barley (cut 15 August and 20 October) and perennial ryegrass following barley harvested at maturity (cut 20 October) after ploughing of 3- and 5-yearold grass-clover swards.

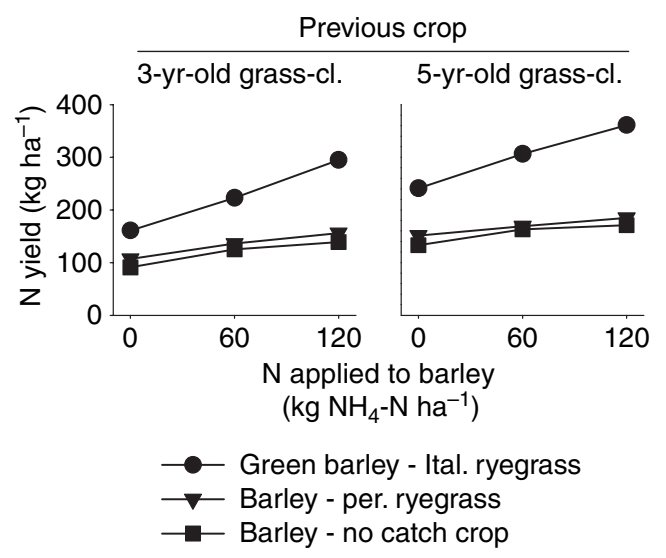

Figure 5 Total N uptake in 2003: in green barley plus Italian ryegrass cuts, and in barley grain and straw harvested at maturity plus the perennial ryegrass cut.

that in this treatment manure $\mathrm{N}$ was taken up by the ryegrass instead of being leached.

Average yields of Italian ryegrass in autumn cuts were 4-6 t DM ha ${ }^{-1}$ (Figure 4). This is similar to the 5.2 t DM ha ${ }^{-1}$ reported by Nielsen et al. (2004) in experiments with Italian ryegrass after barley wholecrop harvest in 2004. A lower yield of the Italian ryegrass after a wholecrop would be expected, because the cereal is usually harvested later than a green crop leaving less time for the development of the catch crop.

\section{Catch crop year 1}

Early establishment of the catch crop is of vital importance for the $\mathrm{N}$ uptake capacity of the catch crop. Vos \& van der Putten (2006) found a decline in potential $\mathrm{N}$ accumulation in the catch crop of $3.4 \mathrm{~kg} \mathrm{ha}^{-1}$ for each day's delay in sowing.
In our experiment, the different harvest times of green and mature barley may act similarly due to limited catch crop growth before harvest of the main crop (see later). If Italian ryegrass had been sown on the day of green barley harvest (17 June, day 168) and the perennial ryegrass on the day of mature barley harvest (11 August, day 223), according to Vos \& van der Putten (2006) the potential N accumulation would have been an estimated $389 \mathrm{~kg} \mathrm{~N} \mathrm{ha}^{-1}$ in Italian ryegrass and $202 \mathrm{~kg} \mathrm{~N} \mathrm{ha}^{-1}$ in perennial ryegrass. The actual $\mathrm{N}$ uptake in the cut Italian ryegrass following barley with $120 \mathrm{~kg} \mathrm{~N} \mathrm{ha}^{-1}$ was 121 and $158 \mathrm{~kg} \mathrm{~N} \mathrm{ha}^{-1}$ after the 3- and 5 -year-old fields, respectively (data not shown). Because the green barley/Italian ryegrass reduced leaching to below $10 \mathrm{~kg} \mathrm{~N} \mathrm{ha}^{-1}$, the Italian ryegrass seems to have been able to take up almost all nitrate present in the soil. If the calculated potential $\mathrm{N}$ accumulation is correct, the Italian ryegrass would have been able to take up even more $\mathrm{N}$. It should be noted that some of the $\mathrm{N}$ taken up was left in stubble in the field.

The actual $\mathrm{N}$ uptake in the perennial ryegrass was only between 11 and $16 \mathrm{~kg} \mathrm{~N} \mathrm{ha}^{-1}$, which is far less than the calculated potential $\mathrm{N}$ accumulation. Leaching under perennial ryegrass in the unfertilized treatment was $86 \mathrm{~kg} \mathrm{~N} \mathrm{ha}^{-1}$ after the 5-year-old grass-clover. This indicates that the perennial ryegrass did not use its full nitrate uptake potential in this field. It should be noted that relatively more of the $\mathrm{N}$ uptake was left in stubble in the less developed perennial ryegrass than the amount left after cutting of the well-developed Italian ryegrass. Weeds growing under cutting height may also have taken up $\mathrm{N}$. The perennial ryegrass catch crop actually reduced nitrate leaching by $66-80 \%$, which implies that much of the $\mathrm{N}$ uptake was in stubble and roots.

In the experiment, the perennial ryegrass treatment was compared with a treatment that was rotovated twice in autumn. This may have increased mineralization of soil organic matter and/or residues from the grass-clover. Results of Andersen \& Olsen (1993) showed a small increase in nitrate content in a coarse sandy soil after three to four stubble cultivation passes. Other results from the same location showed a tendency for increased mineralization when the soil was cultivated in the autumn (Hansen \& Djurhuus, 1997). However, the long-term low input of organic matter in the latter experiment (in contrast to the high input of grassclover residues in our experiment) may have affected mineralization differently after soil cultivation.

Perennial ryegrass has proved its ability to take up $\mathrm{N}$ under Danish climatic conditions. Simmelsgaard (1991) reported an uptake in above ground perennial ryegrass of $76 \mathrm{~kg} \mathrm{~N} \mathrm{ha}^{-1}$. One major difference between our experiment and the experiment of Simmelsgaard (1991) was the timing of $\mathrm{N}$ availability. A large amount of $\mathrm{N}$ was available for the barley crop in our experiment, while the catch crop was unfertilized in the autumn. In the experiment of Simmels- 
gaard (1991), the barley crop was fertilized according to normal practice, and $100 \mathrm{~kg} \mathrm{~N} \mathrm{ha}^{-1}$ was applied to the catch crop in the autumn. This may lead to a difference in competition between the main crop and the catch crop. Strong competition from the growing barley main crop, especially after the 5-year-old field (Figure 2), caused only weak growth or near failure of the undersown perennial ryegrass. Observations in the field indicated that perennial ryegrass had established well, but that the grass was hampered by competition during the growing season. After the 3-year-old grass-clover ley, barley grew less vigorously in the unfertilized treatment and perennial ryegrass survived more satisfactorily, but perennial ryegrass was hampered in this field after application of 60 and $120 \mathrm{~kg} \mathrm{~N} \mathrm{ha}^{-1}$. This shows that the development of the main crop is an important determining factor for the performance of a less competitive catch crop such as late perennial ryegrass. The observation accords with others showing that catch crops such as late perennial ryegrass can have unfavourable conditions for growth when undersown in vigorously growing oats after grass-clover (Tersbøl et al., 2003).

Awareness of competition is especially important in situations with large amounts of available $\mathrm{N}$ and delayed sowing of the catch crop as in our experiment. Here weeds were controlled by a spring tine weeder on 23 April and 9 May 2003 after spring barley germination on 14 April 2003, but before undersowing of the two grasses on 9 May 2003. This means that the undersown grasses were sown later than they would have been in a cropping system without mechanical weed control.

To avoid failure of the catch crop due to a competitive main crop, we recommend that the seed rate of the main crop is reduced, that a competitive catch crop is selected and that the catch crop is established at approximately the same time as the main crop. The latter is only possible in organic farming if weed harrowing after sowing of the main crop is omitted.

\section{Crop year 2}

The residual effects of the treatments in 2003 (Table 4) were determined in a spring barley/perennial ryegrass, which was fertilized with $60 \mathrm{~kg} \mathrm{ha}^{-1}$ ammonium-N in slurry. Thus, in the second year, all treatments were treated identically. After the 3-year-old pasture, there was a significantly higher yield of barley following green barley/Italian ryegrass than following both barley/perennial ryegrass and barley/no catch crop, indicating a positive effect of the Italian ryegrass residues on the following crop. This effect was not observed for the 5-year-old pasture. By contrast, there was a significant yield decrease after perennial ryegrass compared with other treatments. This difference in the effects of the two grasses is believed to be the result of differences in the development of couch grass (Elytrigia repens) (Table 4). Apparently, rotovating twice during autumn 2003 in plots with no catch crop was an effective method of controlling couch grass that year. The limited extent of couch grass following Italian ryegrass (Table 4) also suggests that Italian ryegrass competed better with couch grass than the more sparsely developed perennial ryegrass (Figure 4).

$\mathrm{N}$ uptake in grain and straw did not differ significantly between treatments (Table 4) but tended to be 12-18 kg ha ${ }^{-1} \mathrm{~N}$ less after the 3-year-old than in the 5-yearold pasture.

Table 4 Spring barley yield (85\% DM) and N uptake in 2004, following different treatments in 2003 after spring ploughing of grass-clover swards

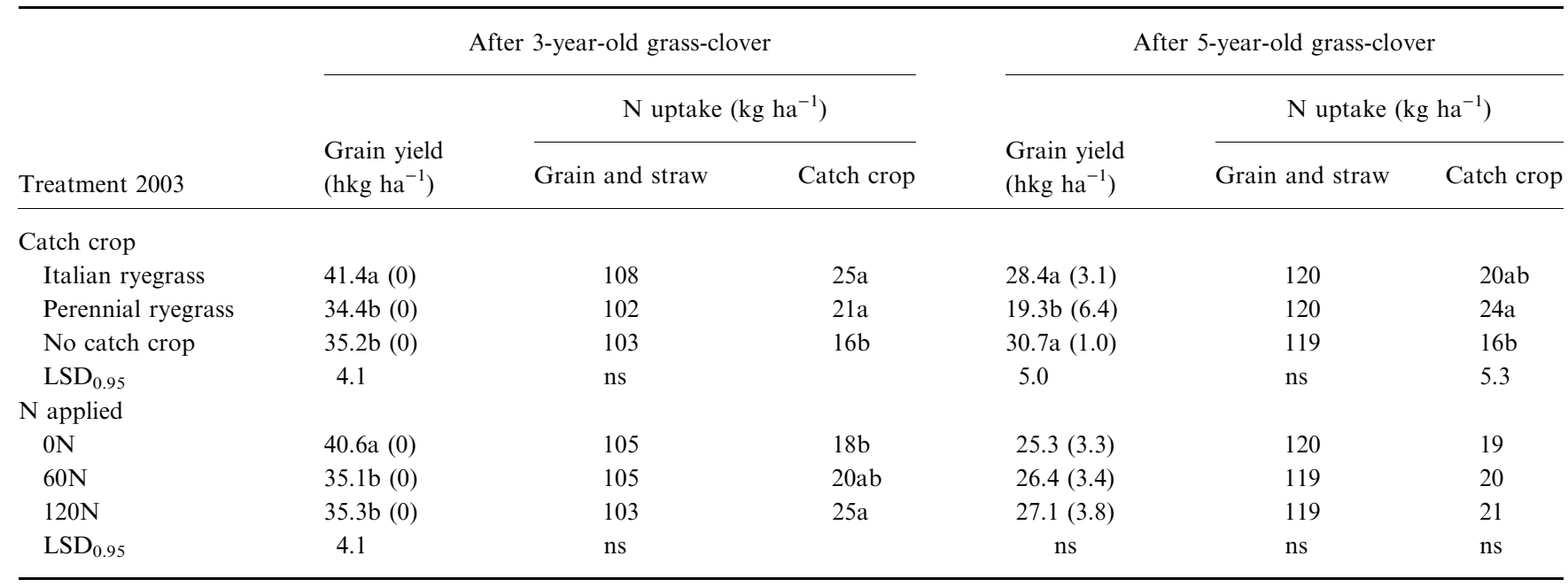

Values followed by the same letter are not significantly different $(P<0.05)$. Bracketed figures show the amount of couch grass $(10=100 \%)$ on 3 November 2004. 


\begin{tabular}{|c|c|c|c|c|}
\hline & \multicolumn{2}{|c|}{2003} & \multicolumn{2}{|c|}{2004} \\
\hline & $\begin{array}{c}\text { After } \\
3 \text { years }\end{array}$ & $\begin{array}{l}\text { After } \\
5 \text { years }\end{array}$ & $\begin{array}{l}\text { After } \\
3 \text { years }\end{array}$ & $\begin{array}{c}\text { After } \\
5 \text { years }\end{array}$ \\
\hline Barley - no catch crop $0 \mathrm{~N}$ & $-262 \mathrm{a}$ & $-367 \mathrm{a}$ & -102 & -118 \\
\hline Barley - no catch crop $120 \mathrm{~N}$ & $-238 \mathrm{a}$ & $-284 a b$ & -105 & -125 \\
\hline Barley - perennial ryegrass $0 \mathrm{~N}$ & $-141 b$ & $-231 b c$ & -85 & -99 \\
\hline Green barley - Italian ryegrass $0 \mathrm{~N}$ & $-169 b$ & $-252 b$ & -100 & -70 \\
\hline Green barley - Italian ryegrass $120 \mathrm{~N}$ & $-105 c$ & $-170 \mathrm{c}$ & -98 & -91 \\
\hline
\end{tabular}

Table $5 \mathrm{~N}$ balance (difference between input of total- $\mathrm{N}$ in manure and output of $\mathrm{N}$ harvested and leached) in $\mathrm{kg} \mathrm{ha}^{-1}$

Significant differences were identified after log-transformation. Means followed by the same letter are not significantly different at the 0.05 level of probability.

\section{$N$ balance}

The $\mathrm{N}$ balance each year was calculated by subtracting $\mathrm{N}$ in the harvested material and leached nitrate from the total-N applied in slurry (Table 5). A negative balance must result from mineralization of grass-clover residues, soil organic matter or from atmospheric deposition. In the first year after ploughing of grass-clover, the balance was strongly negative due to large amounts of $\mathrm{N}$ uptake or high levels of leached $\mathrm{N}$.

In both fields in 2003, the balance was significantly more negative in the treatments where the soil was kept bare during autumn and winter than in the treatments with green barley. This suggests that mineralization in the bare soil was greater than in the soil with Italian ryegrass. This increase could have been due to increased mineralization in the bare soil because of soil cultivation (as discussed above) or to a slower rate of decomposition of organic matter in the treatments with living Italian ryegrass roots (Jenkinson, 1977; Fu \& Cheng, 2002).

The balance in 2003 tended to be more negative in barley/no catch crop treatments without slurry application, than in the same treatment with slurry application, while the slurry effect was statistically significant in green barley/ Italian ryegrass treatments. This implies more mineralization of organic matter in the absence of slurry. It is difficult to explain this result, as the mechanisms of priming effects on mineralization in the short term are probably much more complex than is commonly believed (Fontain et al., 2003) and still not fully understood (Kuzyakov \& Bol, 2006).

The balance does not include leaching of DON. Vinther et al. (2006) measured leaching of $10-11 \mathrm{~kg} \mathrm{ha}^{-1} \mathrm{DON}$ in the green barley/Italian ryegrass without fertilizer application and $20-31 \mathrm{~kg} \mathrm{ha}^{-1}$ DON in the barley/no catch crop treatment with an application of $120 \mathrm{~kg} \mathrm{ha}^{-1} \mathrm{~N}$. If leaching of DON is included in the balance, the differences between barley/no catch crop $(120 \mathrm{~N})$ and green barley/Italian ryegrass $(0 \mathrm{~N})$ were increased.

An overall comparison of the balances for 2003 and 2004 indicates that most of the mineralization took place in the first year after ploughing of the grass-clover in spring 2003 as found by Nevens \& Reheul (2002) and Hansen et al. (2005).

\section{Conclusion}

Cultivation of grassland presents a huge potential for nitrate leaching, which is prevented only through careful management. These experiments showed that a barley silage crop undersown with Italian ryegrass reduced leaching to a minimum in both the experiments with different age and management strategies for the grass-clover leys, and therefore different mineralization potentials after ploughing. This offers advantages not only for the environment but also for farmers, for whom it can provide a fodder high in roughage and avoids the difficulties with clover fatigue increasingly experienced by Danish farmers.

\section{Acknowledgements}

The technical assistance of the staff at Jyndevad experimental Station is gratefully acknowledged. We also wish to thank the farmer Willi Hansen, Bylderup-Bov for allowing us to work in his field.

\section{References}

Andersen, A. \& Olsen, C.C. 1993. Rye grass as a catch crop in spring barley. Acta Agriculturae Scandinavica, Section B, 43, 218230 .

Best, E.K. 1976. An automated method for determining nitratenitrogen in soil extracts. Queensland Journal of Agriculture and Animal Science, 33, 161-166.

Buchmann, N.B., Josefsson, H. \& Cowe, I.A. 2001. Performance of European artificial neural network (ANN) calibration for moisture and protein in cereals using the Danish near-infrared transmission (NIT) network. Cereal Chemistry, 78, 572-577.

Davies, D.B., Garwood, T.W.D \& Rochford, A.D.H. 1996. Factors affecting nitrate leaching from a calcareous loam in East Anglia. Journal of Agricultural Science, Cambridge, 126, 75-86. 
Djurhuus, J. 1992. N-transformation and N-transport in a sandy loam and a coarse sandy soil cropped with spring barley. II. Nitrate leaching. Tidsskrift for Planteavl, 96, 137-152.

Djurhuus, J. \& Jacobsen, O.H. 1995. Comparison of ceramic suction cups and $\mathrm{KCl}$ extraction for the determination of nitrate in soil. European Journal of Soil Science, 46, 387-395.

Djurhuus, J. \& Olsen, P. 1997. Nitrate leaching after cut grass/clover as affected by time of ploughing. Soil Use \& Management, 13, 61-67.

Eriksen, J. 2001. Nitrate leaching and growth of cereal crops following cultivation of contrasting temporary grasslands. Journal of Agricultural Science, Cambridge, 136, 271-281.

Eriksen, J. \& Jensen, L.S. 2001. Soil respiration, nitrogen mineralization and uptake in barley following cultivation of grazed grasslands. Biology and Fertilty of Soils, 33, 139-145.

Eriksen, J., Askegaard, M. \& Kristensen, K. 1999. Nitrate leaching in an organic dairy/crop rotation as affected by organic manure type, livestock density and crop. Soil Use and Management, 15, 176-182.

Eriksen, J., Pedersen, L. \& Jørgensen, J.R. 2006. Nitrate leaching and spring wheat bread making quality following cultivation of grasslands of different composition, age and management. Agriculture, Ecosystems \& Environment, 116, 165-175.

Fontain, S., Mariotti, A. \& Abbadie, L. 2003. The priming effect of organic matter: a question of microbial competition? Soil Biology \& Biochemistry, 35, 837-843.

Fu, S. \& Cheng, W. 2002. Rhizosphere priming effects on the decomposition of soil organic matter in $\mathrm{C}_{4}$ and $\mathrm{C}_{3}$ grassland soils. Plant and Soil, 238, 289-294.

Hansen, B. 1989. Determination of nitrogen as elementary N, as alternative to Kjeldahl. Acta Agriculturae Scandinavica, 39, 113-118.

Hansen, E.M. \& Djurhuus, J. 1997. Nitrate leaching as influenced by soil tillage and catch crop. Soil \& Tillage Research, 41, 203-219.

Hansen, J.P., Eriksen, J. \& Jensen, L.S. 2005. Residual nitrogen effect of dairy crop rotation as influenced by grass-clover ley management, manure type and age. Soil Use and Management, 21, 278-286.

Hauggaard-Nielsen, H., De Neergaard, A., Jensen, L.S., Høgh-Jensen, H. \& Magid, J. 1998. A field study of nitrogen dynamics and spring barley growth as affected by the quality of incorporated residues from white clover and ryegrass. Plant and Soil, 203, 91-101.

Høgh-Jensen, H. \& Schjoerring, J.K. 1997. Residual nitrogen effect of clover ryegrass swards on yield and $\mathrm{N}$-uptake of a subsequent winter wheat crop as studied by use of ${ }^{15} \mathrm{~N}$ methodology and mathematical modelling. European Journal of Agronomy, 6, 235-243.

Jacobsen, A. \& Bentholm, B.R. 1981. Efterafgrøder med lavt ressourceforbrug 1975-80. Oversigt over Landsforsogene 1980, 185186.

Jenkinson, D.S. 1977. Studies on the decomposition of plant material in soil. V. The effects of plant cover and soil type on the loss of carbon from ${ }^{14} \mathrm{C}$ labelled ryegrass decomposing under field conditions. Journal of Soil Science, 28, 424-434.

Karlsson-Strese, E.-M., Rydberg, I., Becker, H.C. \& Umaerus, M. 1998. Strategy for catch crop development. II. Screening of species undersown in spring barley (Hordeum vulgare L.) with respect to catch crop growth and grain yield. Acta Agriculturae Scandinavica, Section B, 48, 26-33.

Kuzyakov, Y. \& Bol, R. 2006. Sources and mechanisms of priming effect induced in two grassland soils amended with slurry and sugar. Soil Biology \& Biochemistry, 38, 747-758.

Kyllingsbæk, A. 1992. Leaching of nitrogen from soil after incorporation of catch crops with different nitrogen concentration. Tidsskrift for Planteavl, 96, 153-161 (In Danish with English summary).

Lord, E.I. \& Shepherd, M.A. 1993. Developments in the use of porous ceramic cups for measuring nitrate leaching. Journal of Soil Science, 44, 435-449.

Macduff, J.H., Jarvis, S.C. \& Roberts, D.H. 1990. Nitrate leaching under grazed grassland: measurements using ceramic cup soil solution samplers. In: Fertilization and the environment (eds. R. Merckx, H. Vereecken \& K. Vlassak), pp. 72-78. Leuven University Press, Belgium.

Madsen, H.B. 1978. Bygs rodudvikling i relation til fysiske parametre i naturlig lejret jord. Tidsskrift for Planteavl, 82, 335-342 (In Danish with English summary).

Nevens, F. \& Reheul, D. 2002. The nitrogen- and non-nitrogen-contribution effect of ploughed grass leys on the following arable forage crops: determination and optimum use. European Journal of Agronomy, 16, 57-74.

Nielsen, K.A., Mikkelsen, M. \& Knudsen, L. 2004. Græs og grønne afgrøder. In: Oversigt over Landsforsogene (ed. C.Å. Pedersen), pp. 306-326. Dansk Landbrugsrådgivning, Landscentret, Planteavl, Århus (In Danish).

Nielsen, K.A., Mikkelsen, M. \& Knudsen, L. 2005. Græs og grønne afgrøder. In: Oversigt over Landsforsogene (ed. C.Å. Pedersen), pp. 325-345. Dansk Landbrugsrådgivning, Landscentret, Planteavl, Århus (In Danish).

Olesen, J.E. \& Heidmann, T. 1990. EVACROP. A programme for calculating daily actual evapotranspiration and runoff from the root zone. Version 1.00. Research Note, Department of Agrometeorology, Research Centre Foulum, Tjele, Denmark (In Danish with English summary).

Shepherd, M.A., Hatch, D.J., Jarvis, S.C. \& Bhogal, A. 2001. Nitrate leaching from reseeded pasture. Soil Use and Management, 17, 97-105.

Simmelsgaard, S.E. 1991. Slutrapport for projektet: Kvælstofudvaskning efter udbringning af kartoffelfrugtsaft. Statens Planteavlsforsøg. Internal report. Danish Institute of Plant and Soil Science, Tjele, Denmark (In Danish).

Simmelsgaard, S.E. 1998. The effect of crop, N-level, soil type and drainage on nitrate leaching from Danish soil. Soil Use and Management, 14, 30-36.

Søegaard, K. \& Møller, K. 2006. Can higher legume diversity reduce clover soil fatigue? Joint Organic Congress. Odense, Denmark. Available at: http://orgprints.org/7542/01/Karen_Soegaard.rtf, May 2006.

Tersbøl, M., Bertelsen, I., Mejnertsen, P., Nielsen, G.C. \& Pedersen, J.B. 2003. Økologisk dyrkning. In: Oversigt over Landsforsogene (ed. C.A. Pedersen), pp. 204-244. Dansk Landbrugsrådgivning, Landscentret, Planteavl, Århus (In Danish).

Thomsen, I.K. \& Christensen, B.T. 1999. Nitrogen conserving potential of successive ryegrass catch crops in continuous spring barley. Soil Use \& Management, 15, 195-200. 
Torstensson, G. \& Aronsson, H. 2000. Nitrogen leaching and crop availability in manured catch crop systems in Sweden. Nutrient Cycling in Agroecosystems, 56, 139-152.

Trinsoutrot, I., Recous, S., Bentz, B., Linères, M., Chèneby, D. \& Nicolardot, B. 2000. Biochemical quality of crop residues and carbon and nitrogen mineralization kinetics under nonlimiting nitrogen conditions. Soil Science Society of America Journal, 64, 918-926.
Vinther, F.P., Hansen, E.M. \& Eriksen, J. 2006. Leaching of soil organic carbon and nitrogen in sandy soils after cultivating grassclover swards. Biology and Fertility of Soils, 43, 12-19.

Vos, J. \& van der Putten, P.E.L. 2006. Nitrogen catch crops: their performance and effect in relation to the EU nitrate directive. In: Proceedings of the $14^{\text {th }}$ Workshop, October 2005, Maastricht, the Netherlands. 